\title{
KAJIAN PARTIKEL ARANG DAUN BAMBU TUTUL HASIL TUMBUKAN HIGH ENERGY BALL MILLING TIPE SHAKER MILL.
}

\author{
Yoyo Saputro, Supriyono, Agus Dwi Anggono \\ ${ }^{1}$ Teknik Mesin Universitas Muhammadiyah Surakarta \\ Jl. A. Yani Tromol Pos 1 Pabelan, Kartosuro
}

\begin{abstract}
ABSTRAK
Arang daun bambu tutul sebagai kajian produk nanopartikel dan penghasil silica yang memiliki berbagai keunggulan dari segi sifat fisika dan kimia. Pada penelitian ini produksi nanopartikel menggunakan High Energy Milling (HEM) tipeshaker mill untuk memproduksi nanopartikel dari arang daun bambu tutul. Pada penelitian ini dilakukan uji PSA untuk menganalisa ukuran partikel, untuk menganalisa distribusi morfologi partikel dan komposisi kimia yang terkandung dalam material menggunakan uji SEM dan EDX. Siklus yang digunakan pada penelitian adalah 2 juta siklus dengan putaran motor listrik 1000 rpm, dan diameter bola baja 1/4 inchi. Tabung stainless steel berjumlah 4 dengan diameter tabung 2 inchi dan tinggi tabung $120 \mathrm{~mm}$ dengan perbandingan volume ruang kosong tabung yaitu 1:1, 1:2, 1:3, dan 1:4 dengan material. Penelitian ini bertujuan untuk mengetahui pengaruh volume ruang kosong tabung dan rata - rata diameter partikel, distribusi partikel, dan komposisi yang terkandung dalam partikel hasil tumbukan dengan alat shaker mill. Hasil penelitian ini menunjukkan bahwa volume ruang kosong tabung sangat berpengaruh pada mekanisme tumbukan. Dari uji PSA semakin besar volume ruang kosong tabung, semakin kecil ukuran partikel material yang dihasilkan. Hasil uji SEM dan EDX didapatkan unsur kimia karbon yang paling tinggi 68,47\% pada volume 1:1 ruang kosong tabung. Sehingga arang daun bambu tutul merupakan sumber potensi sebagai penghasil silica.
\end{abstract}

Kata kunci: Arang Daun Bambu Tutul, Nanopartikel, High Energy Milling (HEM), Silika.

\section{PENDAHULUAN}

Bambu masuk dalam jenis tanaman rerumputan, yang tumbuh dengan cara penyebaran perakaran dan rhizomanya di bawah tanah. Akar bambu terdapat di bawah permukaan tanah dan membentuk system percabangan. Batang-batang bambu muncul dari akar rimpang dan ketika menua, batang mengeras dan biasanya berongga, setelah sebelumnya muncul tunas dari permukaan dasar rumput yang biasannya orang menyebutnya dengan nama rebung. Daun bambu merupakan jenis daun yang lengkap karena memiliki bagian-bagian seperti pelepah daun, tangki daun, dan helaian daun.yang berbentuk langset, ujung daunnya meruncing, pangkal daun tumpul, tepi daun merata, dan daging daun seperti kertas. Pertulangan daun bambu sejajar, yaitu mempunyai satu tulang di tengah yang besar sedangkan tulang-tulang lainnya lebih kecil dan tampak sejajar dengan ibu tulang daun.Permukaan daun bagian atas berbulu, sedangkan permukaan daun bagian bawah berbulu kasar. Bagian atas daun berwarna hijau cerah sedangkan permukan bagian bawahnya hijau gelap.

Salah satu jenis bambu wulung ini sangat mudah dijumpai di Indonesia. Walaupun jauh dari penyebarannya yakni wilayah asia tropis:India dan kawasan Malaysia, namun sekarang bambu tutul sering dijumpai di pedesaan jawa, terutama jawa tengah dan jawa barat, karena sangat bermanfaat untuk dibuat angklung, bambu ini banyak tumbuh di daerah tropis yang 
lembab, bambu wulung terkenal dengan nama bambu hitam atau pring ireng karena batangnya berwarna hijau kehitaman tak jarang ditemukan pula berwarna hijau semu ungu tua, beda dengan tanaman bambu lainnya bambu tutul pertumbuhannya agak lambat dan memiliki sifat tidak begitu keras saat basah, namun ketika bambu ini dalam keadaan kering bisa sagat keras sehingga daya lemturnya kurang dan menjadikannya mudah pecah dan putus [1].

Perkembangnya zaman dan teknologi mengakibatkan kebutuhan akan penelitian dan pengembangan dalam segala bidang semakin meningkat pesat, terutama dibidang material. Hal yang mendasar pada kemajuan teknologi adalah semakin dibutuhkannya material baru guna menunjang bidang industri yang lain. Penelitian ini memfokuskan dalam material karbon, dengan terbatasnya sumber dana diharapkan nantinya dapat memberi solusi untuk pengembangan dan pemanfaatan nanoteknologi di Indonesia. Nanopartikel telah dijadikan kajian yang sangat menarik, oleh karena itu nanopartikel merupakan suatu partikel yang didefinisikan sebagai obyek kecil yang berperilaku sebagai satu kesatuan terhadap sifat transportasinya yang menunjukan sifat yang baru atau lebih baik berdasarkan karakteristik dibandingkan dengan partikel bulk yang lebih besar [2].

Sehingga nanopartikel merupakan salah satu bidang yang menarik minat banyak peneliti. Nanopartikel dapat terjadi secara alamiah ataupun melalui proses sintesis oleh manusia. Sintesis nanoparikel bermakna pembuatan nanopartikel dengan ukuran yang kurang dari 100 $\mathrm{nm}$ dan sekaligus mengubah sifat atau fungsinya. Nanopartikel merupakan suatu partikel yang didefinisikan sebagai objek kecil yang berperilaku sebagai satu kesatuan terhadap sifat transportasinya yang menunjukan sifat baru atau lebih baik berdasarkan karakteristik dibandingkan dengan partikel bulk yang lebih besar [3].

\section{TINJAUAN PUSTAKA}

Penelitian tentang pemanfaatan mengunakan bambu wulung sebagai produksi nanopartikel pernah dilakukan oleh joharwan et all. (2017), dalam penelitiannya dengan perbandingan siklus 2 juta, 3 juta, dan 4 juta tumbukan, dengan perbandingan bola baja 1/8, 5/32, 3/16, dan 1/4 inchi [4].

Mei et all. (2006), Dalam penelitiannya melakukan penelitian karbon nanopartikel yang berbentuk cobble seperti diameter 21-198 nm didinding sel serat bambu. Nanograins ini adalah blok bangunan dasar yang digunakan untuk membangun serat bambu individu. Serat bambu nanograins terstruktur tidak rapuh tetapi sedikit lentur [5].

Kumar et all. (2016), Telah melakukan penelitian bambu mentah menjadi produk terkompres atau dilaminasi dengan resin thermosetting dengan kerapatan 800-1200 kg. tujuan penelitian ini untuk mengetahui pengaruh kerapatan kerang bambu pada sifat mekanik [6].

Sharma et all. (2015), Membuat penelitian pengolahan batang bambu menjadi komposit berlapis yang mirip dengan produk kayu dilaminasi. Tujuan penelitian ini untuk membandingkan lembaran bambu laminasi dengan kayu rekayasa [7].

Agung et all. (2013), Melakukan penelitian temperature pemanasan dan waktu pemanasan terhadap yield silica yang dihasilkan dari sekam padi. Penelitian ini menggunakan rancangan desain factorial dengan dua level dan tiga variabel yaitu temperature pemanasan, waktu pemanassan, dan konsentrasi basa dengan jumlah percobaan 8 kali dengan ulangan sebanyak 2 kali [8].

\section{KAJIAN TEORI}

Nanopartikel adalah partikel yang berukuran antara 1 sampai 1.000 nanometer. Dalam nanoteknologi, suatu partikel didefinisikan sebagai obyek kecil yang berperilaku sebagai satu kesatuan terhadap sifat dan transportasinya. Partikel lebih jauh diklasifikasikan menurut 
diameternya. Partikel ultrahalus serupa dengan nanopartikel dan berukuran antara 1 sampai 100 nanometer, partikel halus berukuran antara 100 sampai 1.000 nanometer. Pengembangan metoda sintesis nanopartikel merupakan salah satu bidang yang menarik minat banyak peneliti. Nanopartikel dapat terjadi secara alamiah ataupun melalui proses sintesis oleh manusia. Sintesis nanoparikel bermakna pembuatan nanopartikel dengan ukuran yang kurang dari 100 $\mathrm{nm}$ dan sekaligus mengubah sifat atau fungsinya. Nanopartikel merupakan suatu partikel yang didefinisikan sebagai objek kecil yang berperilaku sebagai satu kesatuan terhadap sifat transportasinya yang menunjukan sifat baru atau lebih baik berdasarkan karakteristik dibandingkan dengan partikel bulk yang lebih besar [9]. Dua hal utama yang membuat nanopartikel berbeda dengan material sejenis dalam ukuran besar (bulk) yaitu:

1. Karena ukurannya yang kecil, nanopartikel memiliki nilai perbandingan antara luas permukaan dan volume yang lebih besar jika dibandingkan dengan partikel sejenis dalam ukuran besar. Ini membuat nanopartikel bersifat lebih reaktif. Reaktivitas material ditentukan oleh atom-atom di permukaan, karena hanya atom-atom tersebut yang bersentuhan langsung dengan material lain;

2. Ketika ukuran partikel menuju orde nanometer, maka hukum fisika yang berlaku lebih didominasi oleh hukum- hukum fisika kuantum. Sifat-sifat yang berubah pada nanopartikel biasanya berkaitan dengan fenomena-fenomena berikut ini. Pertama adalah fenomena kuantum sebagai akibat keterbatasan ruang gerak elektron dan pembawa muatan lainnya dalam partikel. Fenomena ini berimbas pada beberapa sifat material seperti perubahan warna yang dipancarkan, transparansi, kekuatan mekanik, konduktivitas listrik, dan magnetisasi. Kedua adalah perubahan rasio jumlah atom yang menempati permukaan terhadap jumlah total atom. Fenomena ini berimbas pada perubahan titik didih, titik beku, dan reaktivitas kimia. Perubahan-perubahan tersebut diharapkan dapat menjadi keunggulan nanopartikel dibandingkan dengan partikel sejenis dalam keadaan bulk.

\section{Sifat Nanopartikel}

Nanopartikel merupakan sifat yang baru atau lebih baik berdasarkan karakteristik spesifik (ukuran, distribusi, morfologi, fasa, dll), jika dibandingkan dengan partikel bulk yang lebih besar.

1. Luas permukaan spesifik $\left(\mathrm{m}^{2} / \mathrm{g}\right)$

Nanopartikel menghadirkan rasio volume yang lebih tinggi dengan ukuran partikel nano yang semakin berkurang. Luas permukaan spesifik lebih relevan untuk reaktivitas katalitik dan sifat terkait lainnya (kekasaran) dan antarmuka dengan material pendukung lainnya juga merupakan aspek yang relevan.

2. Sifat termal

Secara umum nanopartikel memiliki titik lebur yang lebih rendah dan panas spesifik yang lebih tinggi dibanding sifat bulk-nya. Kemudian reduksi ukuran ke skala nano akan menurunkan suhu sintering dan suhu pengkristalan dikarenakan kandungan energy permukaannya yang tinggi.

3. Sifat mekanik

Kekerasan dan kekuatan dari bahan logam dan aloy berukuran nano dapat meningkatkan sampai dengan satu order diatas ukuran normalnya. Ketika bahan keramik direduksi sampai skala nano sifat duktilitasnya meningkat sangat signifikan.

4. Sifat listrik

sifat konduktivitas cenderung mengalami pembalikan ketika terjadi reduksi ukuran. Nanokeramik dan nanokomposit memiliki kecenderungan menghantarkan listrik sedangkan 
nanologam menjadi bersifat isolator. Contohnya $\mathrm{Cu}$, nanopartikel bersifat isolator sedangkan $\mathrm{SiO} 2$ nanopartikel bersifat penghantar listrik yang baik.

5. Sifat katalis

Nanomaterial cenderung memiliki aktivitas katalis yang lebih baik. Hal ini disebabkan luas permukaan yang bertambah dan atom diujung-ujung permukaan semakin banyak mengakibatkan bertambahnya reaktivitas dari bahan tersebut.

Hosokawa et all. (2007), Indonesia merupakan Negara yang sangat kaya dengan sumber daya alam yang potensial, didukung dengan keadaan geografis indonesia. Adapun salah satu sumber daya alam yang ada di indonesia adalah bambu. Bambu merupakan tanaman Ordo Bamboo idea yang pertumbuhannya cepatdan bambu dapat dipanen pada umur 3 tahun dan memiliki jumlah produksi yang tinggi.Bambu mengandung silikat yang cukup tinggi, bambu memiliki komposisi kimia diantaranya terdapat unsur silikat yang terkandung didalam bambu. Hal ini silikat merupakan senyawa yang umum ditemukan dalam kehidupan sehari-hari dan banyak digunakan dalam aplikasi elektronik, keramik, adsorben semen, katalisator, dan masih banyak lagi pemanfaatannya. Dengan keterbatasan sumber daya, material silika diharapkan dapat menjadi salah satu solusi untuk pengembangan nanoteknologi. Nanoteknologi sudah digiatkan diberbagai benua baik Amerika, Australia, sebagian Eropa dan sebagian Asia, namun di Indonesia masih dalam tahap rintisan [10]

Proses pembakaran daun bambu akan menghasilkan arang yang menghasilkan unsur kimia Carbon sebesar 68,47 \%, Silicon dioxide 22,59\% untuk mengetahui hasil tersebut menggunakan uji EDX. Proses pembuatan Carbon dan Silicon dioxide dengan cara ditumbuk menggunakan alat Shaker mill. Sehingga daun bambu mendapatkan komposisi kimia yang terkandung dalam material hasil tumbukan.

\section{METODOLOGI PENELITIAN}

\section{Alat dan Bahan}

Peralatan yang digunakan dalam pengujian adalah sebagai berikut:

1. Shaker mill

2. Tabung Stainless steel

3. Bola baja1/4 inchi

4. Takaran Material

5. Corong plastik

6. Centrifuge

Sedangkan bahan yang digunakan dalam pengujian ini adalah sebagai berikut :

1. Arang daun bambu tutul

2. Aqua Pro Injection

\section{Tahapan Pembuatan Nanopartikel}

Pembuatan Nanopartikel melalui tahapan sebagai berikut (a) Persiapan bahan baku, daun bambu wulung dikeringkan, kemudian dibakar dengan pembakaran tidak sempurna didalam kaleng sampai daun menjadi arang (b) Angkat arang tersebut kemudian dimasukan ketabung untuk ditumbuk menggunakan alat shaker mill (c) Keluarkan arang yang sudah ditumbuk untuk dilakukan penyaringan menggunakan ayakan (d) Kemudian arang yang sudah diayak di uji PSA untuk mengetahui ukuran suatu partikel dengan prisip kerja menggunakan sinar laser (e) Tahapan selanjutnya di uji SEM dan EDX untuk mengetahui gambaran bentuk permukaan dari material yang dianalisis dan hasil unsur kimia. 


\section{Pengujian kinerja Alat}

Pengujian kinerja alat shaker mill untuk menghasilkan partikel - partikel nanopartikel sebelum di uji menggunkan uji PSA dan SEM-EDX. Setelah di uji menggunkan uji PSA dan SEM-EDX akan diketahui hasil ukuran partikel dan hasil unsur kimia.

\section{Teknik Analisa Data}

Penelitian ini menggunakan perbandingan volume tabung Stainless steel. Dimana data yang diperoleh dari hasil tumbukan menggunakan alat shaker mill dimasukan ke dalam tabel, dan ditampilkan dalam bentuk grafik kemudian dibandingkan dan dianalisis ukuran pertikel dan hasil unsure kimia yang menggunakan uji PSA dan SEM-EDX.

\section{HASIL DAN PEMBAHASAN Analisa Hasil Pengujian PSA}

Tabel 1. Hasil Pengujian PSA

\begin{tabular}{cc}
\hline $\begin{array}{c}\text { Perbandingan volume ruang } \\
\text { kosong tabung dengan material }\end{array}$ & Ukuran Partikel(nm) \\
\hline $1: 1$ & 627,3 \\
$1: 2$ & 795 \\
$1: 3$ & 801,2 \\
$1: 4$ & 836,36 \\
\hline
\end{tabular}

Dari pengujian PSA (Particle SizeAnalyzer) akan diketahui ukuran partikel dari bahan yang diuji. Alat uji yang digunakan yaitu PSA Horiba SZ-100 dengan pembacaan scala micrometer sampai dengan nanometer. Hasil PSA (Particle SizeAnalyzer) berupa rata-rata diameter partikel.

Kemudian hasil perbandingan volume ruang kosong tabung dengan material dapat dilihat grafik dibawah ini:

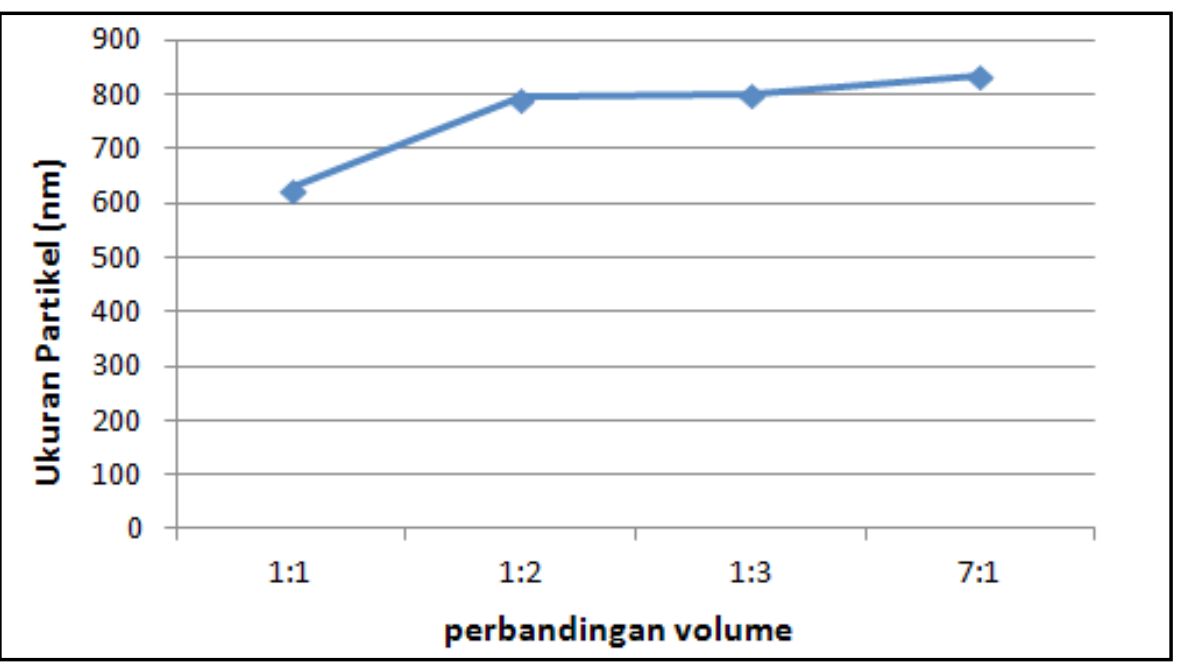

Gambar 1. Diagram hasil pengujian PSA dengan perbandingan volume1:1, 1:2, 1:3, dan 1:4 ruang kosong tabung dan material 
Pada tabel 1. hasil pengujian PSA, menunjukan bahwa perbandingan volume ruang kosong tabungdan material 1:1 menghasilkan ukuran partikel yang paling kecil. Hal ini disebabkan pada volume ruang kosong tabung yang besar mempunyai luas bidang kontak (bola baja dan arang daun bambu) yang lebih besar, sehingga dapat menghasilkan partikel dengan ukuran yang kecil.

\section{Analisa Hasil Pengujian SEM}

Hasil uji SEM berupa foto dengan pembesaran 3000x dan 10000x pembesaran, dengan perbandingan volume ruang kosong tabung dan material.

a.

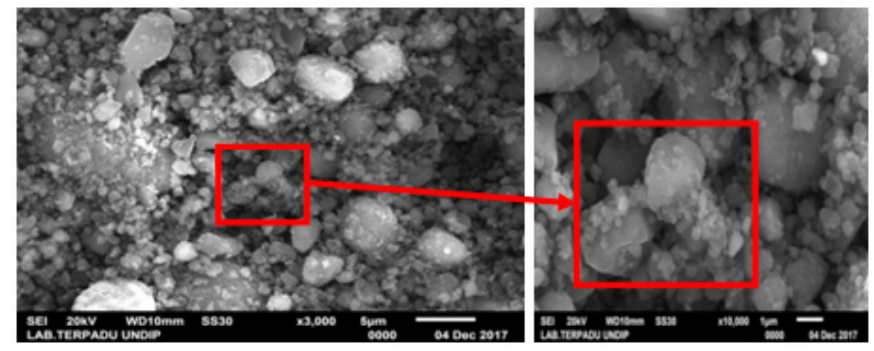

Gambar a. Hasil uji SEM volume 1:1 dengan pembesaran 10000x

b.
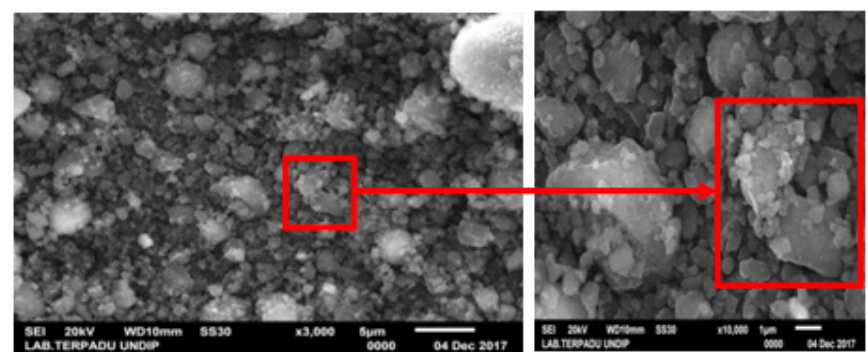

Gambar b. Hasil uji SEM volume 1:2 dengan pembesaran 10000x

c.
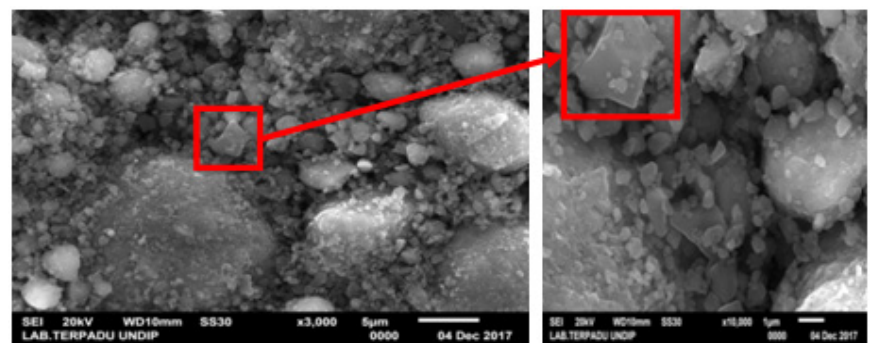

Gambar c. Hasil uji SEM volume 1:3 dengan pembesaran 10000x

d.
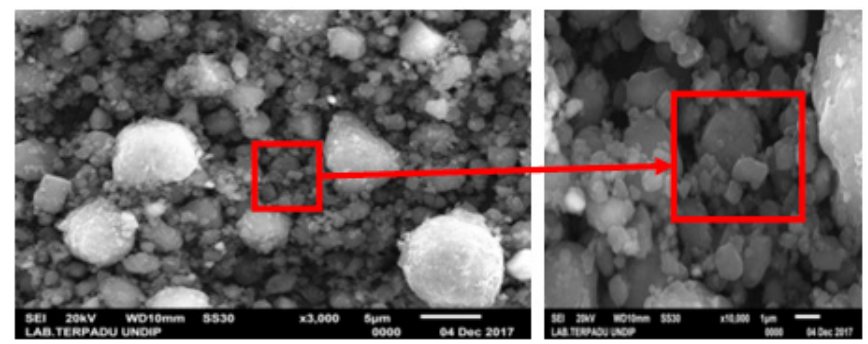

Gambar d. Hasil uji SEM volume 1:4 dengan pembesaran 10000x 
Dari hasil uji SEM menunjukan bahwa material hasil tumbukan pada perbandingan volume ruang kosong tabung dan material 1:1 lebih homogen dibandingkan perbandingan volume yang lain. Hal ini disebabkan pada material hasil tumbukan perbandingan volume 1:1 mempunyai ukuran ukuran partikel yang lebih kecil, sehingga material hasil tumbukan mempunyai kerapatan yang lebih besar.

\section{Analisa Hasil Pengujian EDX}

Hasil uji EDX ditunjukan pada tabel dibawah ini berupa komposisi unsur kimia yang terkandung dalam material hasil tumbukan.

Tabel 2. hasil uji EDX dengan perbandingan volume ruang kosong dan material

\begin{tabular}{ccccc}
\hline \multirow{2}{*}{$\begin{array}{c}\text { Unsur } \\
\text { kimia }\end{array}$} & $\begin{array}{c}\text { Perbandingan } \\
\text { Volume } 1: 1\end{array}$ & $\begin{array}{c}\text { Perbandingan } \\
\text { Volume } 1: 2\end{array}$ & $\begin{array}{c}\text { Perbandingan } \\
\text { Volume } 1: 3\end{array}$ & $\begin{array}{c}\text { Perbandingan } \\
\text { Volume 1:4 }\end{array}$ \\
\hline $\mathrm{C}$ & 67,21 & 66,14 & 67,09 & 68,47 \\
$\mathrm{MgO}$ & 0,66 & 0,66 & 0,66 & 0,66 \\
$\mathrm{Al}_{2} \mathrm{O}_{3}$ & 1,02 & 1,02 & 1,02 & 1,01 \\
$\mathrm{SiO}_{2}$ & 24,09 & 21,39 & 23,19 & 22,59 \\
$\mathrm{SO}_{3}$ & 0,46 & 0,43 & 0,48 & 0,43 \\
$\mathrm{Cl}_{1}$ & 0,15 & 0,16 & 0,16 & 0,19 \\
$\mathrm{~K}_{2} \mathrm{O}$ & 0,50 & 0,50 & 0,52 & 0,51 \\
$\mathrm{C}_{\mathbf{3}} \mathrm{O}$ & 2,19 & 1,90 & 1,43 & 1,87 \\
$\mathrm{~F}_{8} \mathrm{O}$ & 0,99 & 0,87 & 1,18 & 1,23 \\
$\mathrm{CuO}_{\mathrm{n} O}$ & 0,92 & 0,82 & 0,80 & 0,76 \\
$\mathrm{ZnO}$ & 1,10 & 1,15 & 1,10 & 1,22 \\
$\mathrm{ZrO}$ & 0,69 & 0,97 & 0,87 & 1,07 \\
\hline
\end{tabular}

Pada tabel Hasil EDX pada 2 juta siklus, menunjukan bahwa perbandingan volume ruang kosong tabung dan material 1:4 menghasilkan unsur karbon (C) yang paling banyak yaitu 68,47 $\%$. Hal ini disebabkan semakin kecil ruang kosong yang digunakan maka tingkat aglomerasi material akan semakin besar.

\section{KESIMPULAN}

Dari penelitian ini dapat ditarik beberapa kesimpulan sebagai berikut :

1. Dari hasil uji PSA, Semakin besar volume ruang kosong tabung maka semakin kecil ukuran partikel material yang dihasilkan. Hal ini disebabkan pada volume ruang kosong yang besar mempunyai luas bidang kontak (bola baja dan arang bambu) yang lebih besar, sehingga dapat menghasilkan partikel material dengan ukuran yang kecil.

2. Dari hasil SEM, Semakin besar volume ruang kosong tabung maka tingkat homogenitas partikel material yang dihasilkan semakin besar. Hal ini disebabkan pada material hasil tumbukan pada perbandingan volume 1:1 mempunyai ukuran partikel yang lebih kecil, sehingga material hasil tumbukan mempunyai kerapatan yang lebih besar. 
3. Dari hasil EDX pada 2 juta siklus, Semakin kecil volume ruang kosong tabung maka aglomerasi material semakin besar. Hal ini disebabkan semakin kecil ruang kosong yang digunakan maka tingkat aglomerasi material akan semakin besar.

\section{DAFTAR PUSTAKA}

[1] Anonim. (2007). Bambu. https://id.wikipedia.org/wiki/Bambu. Diakses tanggal 12 August 2009

[2] Charomaini, (2013). Budidaya Bambu Jenis Komersial. Institut Pertanian Bogor., vol.1, pp. 17-20

[3] Anonim. https://id.wikipedia.org/wiki/Nanopartikel. Diakses tanggal 6 December 2016

[4] Joharwan, Supriyono. (2017). Produksi nanopartikel arang bambu wulung dengan menggunakan High Energy Milling (HEM) model shaker mill.p1-5

[5] Mei, F., Liu, C., Zhang, L., Ren, F., Zhou, L., Zhao, W. K., \& Fang, Y. L. (2006). Microstructural study of binary $\mathrm{TiO} 2$ : SiO 2 nanocrystalline thin films. Journal of Crystal Growth. vol.1, p87-91

[6] Kumar, A., Vlach, T., Laiblova, L., Hrouda, M., Kasal, B., Tywoniak, J., \& Hajek, P. (2016). Engineered bamboo scrimber : Influence of density on the mechanical and water absorption properties. Construction and Building Materials. vol.2, p815-827

[7] Sharma, B., Gatóo, A., Bock, M., \& Ramage, M. (2015). Engineered bamboo for structural applications. Construction and Building Materials. vol.81, p66-73

[8] Agung, G. F., Hanafie, M. R., \& Mardina, P. (2013). Ekstraksi Silika Dari Abu Sekam Padi Dengan Pelarut Koh. Konversi.,vol.2, p 28-31

[9] Martien, R., Adhyatmika, Irianto, I. D. K., Farida, V., Dian, \& Sari, P. (2012). Technology Developments Nanoparticles As Drug. Majalah Farmaseutik. vol.1, p133-144.

[10] Hosokawa. (2007). Mechanical Milling a Top Down Approach for the Synthesis of Nanomaterials and Nanocomposites, Journal Powder Technologi, vol.1, p7-42 